\title{
本邦温泉の地域性について
}

其の 1 . 火山地帶溫泉

$$
\text { 中 村 久 由* }
$$

\section{On Regional Properties of Hot Springs in Japan}

1. Hot springs distributed in younger volcanic areas

BY

Hisayoshi Nakamura

Abstract

Hot springs in Japan are divided into three groups which are distributed respetively in younger volcanic, semi-volcanic and non-volcanic areas, according to the relation of younger volcanic zones to hot springs. On the other hand, hot springs are classified into two types, namely the one high in $\mathrm{Cl}^{\prime}$ content and the other moderate. Hot springs characterized by high content of $\mathrm{Cl}^{\prime}$ derived from aqueous or igneous origin are situated in tertiary oil fields, tertiary volcanic or hypabyssal rock areas and granite areas.

The following phenomena recognized in thermal areas are important to know properties of hot springs distributed in younger volcanic areas :

(1) Volcanic gases are higher in content of $\mathrm{HCl}$ than fumarolic gases.

(2) Hot springs emitted from fumarolic areas are divided into two types, the one is saline water type characterized by higher content of $\mathrm{Cl}^{\prime}$ and the other is ground water type by lower of $\mathrm{Cl}^{\prime}$ in ground water.

(3) According to the abundance of $\mathrm{Cl}^{\prime}$ content in thermal areas, there are two types of hot springs in the centre of thermal activity of altered rock areas. One is the type showing high content of $\mathrm{Cl}^{\prime}$, the other is low.

The above-mentioned phenomena are considered to depend upon the diffusing flow of volcanic or fumarolic gases through the mother rocks and the depth of circulating ground water. Accordingly, it is probable that $\mathrm{HCl}$ contained in volcanic gases is not only dissolved in deep vadose water, but also fixed as halide salts in the wall rocks on the way up to the surface from a volatile source.

Properties of hot springs of such a various range from acidic to alkaline, distributed in younger volcanic areas seems to be influenced by shallow volcanic or fumarolic action in addition to the diffusing flow of volcanic or fumarolic gases and the ascending distance of thermal water to the surface.

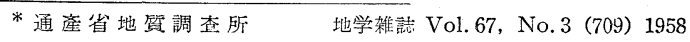




\section{まえがき}

我国に和ける温泉の分布をみると, 殆ど大部分は第四紀以降のいるゆる火山帯に密接に相伴つて存在す ることが判る。然し, 温泉の中沉少数ではあるが,この火山帯からはずれた地域位位置するものもある。

この上うに, 分布の上からみただけでも, 温泉と火山活動との間に, 密接な関連のあることがうかがわ れる。然し, 火山帯というのは新期火山の地理的な分布を連㸚たるのであるから, 火山帯の中に包含され る地域であつても，場所によつて新期火山の存在する地域と，その近くに火山の存在しないところとが当 然出てくる。

一方，新期火山の存在地域は，同時に第三紀上降に括ける火山活動の旺盛な地域に当るので，温泉は第 三紀の火山岩・半深成岩・深成岩および火山性堆積物を母岩として涌出する場合が少なくない。また，こ れらの第三紀火成岩だけごなく各地質時代の岩層を湧出母岩とする湧泉の中で地域的に 水成源あるいは火 成源の高战泉で特徵づけられる幾つかの温泉ないし鉱泉がある。地域的にみると，前者は日本海に沿らい わゆる油田地带の温泉が主であり, 後者は第三紀火山岩ないし半深成岩地带和よび花崗岩地带に 存在する 幾つかの温泉・鉱泉である。これらの高被泉は, 温泉の地域性を考元る上飞重要な意義をるち, からその

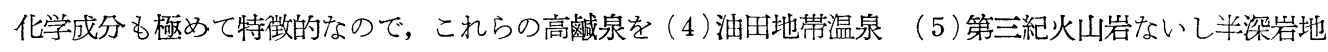
带温泉（6）崗岩地带温泉と呼ぶことにする。

本文は数多い我国の温泉を地域別にとりあげ，扔の和のどのような特徵をるち，かつ，その成因的系統 がどのように分たれるかという問題に触れたものである。以下, 先づ, 火山地带温泉の諸性質を検討して みることにする。

本文を述べるに先立ち, 内容について種々御検討いたぶいた東京都立大学教授野口喜三雄博士拉よび各 地の調相に協力を願つた本所前田憲二郎・鈴木孝両技官に対して深甚の謝意を表する次第である。

\section{I. 火山地帶温泉}

新期火山体およびその周辺に存在する温泉であつた, 現在な和噴気露頭を有するものを始め变質帯を伴

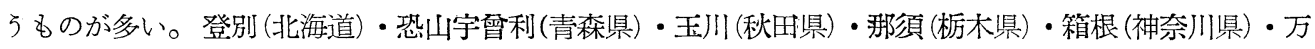
座(群馬県)・霧島 (鹿児島県) 等がその代表的な例である。

1. 火山地带温泉の基碟

（1）火山ガス敊よび噴気ガスの特性

温泉の分布が主に新期の火山帯に伴うことは既沉述べた通りであるが，この点，現に活動を続ける火山 から灼熱の熔岩が流れ，また高温のガス体を発散するなどの事実からみて温泉と火山作用との間に密接な 関連が存在することについては殆ど疑問の余地がないようである。

いま, 火山作用に伴う諸現象の中から, 最も活動の旺盛な時期に発散するいわゆる火山ガスを取上げ, その成分的特徴をあげてみると(第 1 表)，次の事柄を指摘することができる。すなわち，この火山ガスは 殆ど例外なく掹化水素 ( $\mathrm{HCl})$ を伴うことである。次に，一般にいう噴気地带から発散する噴気ガスにつ いて, その特徵とみられる点を検討してみると, それは前者とは対立的に殆ど塩化水素を含まず，炭酸ガ ス $\left(\mathrm{CO}_{2}\right)$ 特よび硫化水素ガス $\left(\mathrm{H}_{2} \mathrm{~S}\right)$ などの弱酸性のガスを含有するとい5点にある。これ迄に行われ た噴気ガスの分析は，主に自然の噴気露頭だけに限られていたが，1948年，大分県別府南立石の試錐孔か ら噴出したいわゆる天然蒸気は, 噴気ガスの化学性について貴重な資料”を提供した。すなわち, 第 2 表 はその測定結果の一部であるが，この表をみると，たとえ過熱蒸気を噴出するょうな場合であつてる，噴 気ガス成分のみならず，その凝縮水の中にも塩酸の存在が殆ど認められず，自然状態に近い噴気ガスの性 質を知る上に極めて注目すべき特性を示している。

このように，火山ガスと噴気ガスの両ガス成分を比較してみた場合，その各々を特徴づける $\mathrm{HCl}$ の消 長が，いわゆる火山ガスの流動関連があると考古て，さして不都合でない上うに思われるが，この現象 
第 1 表 火口ガス化学成分

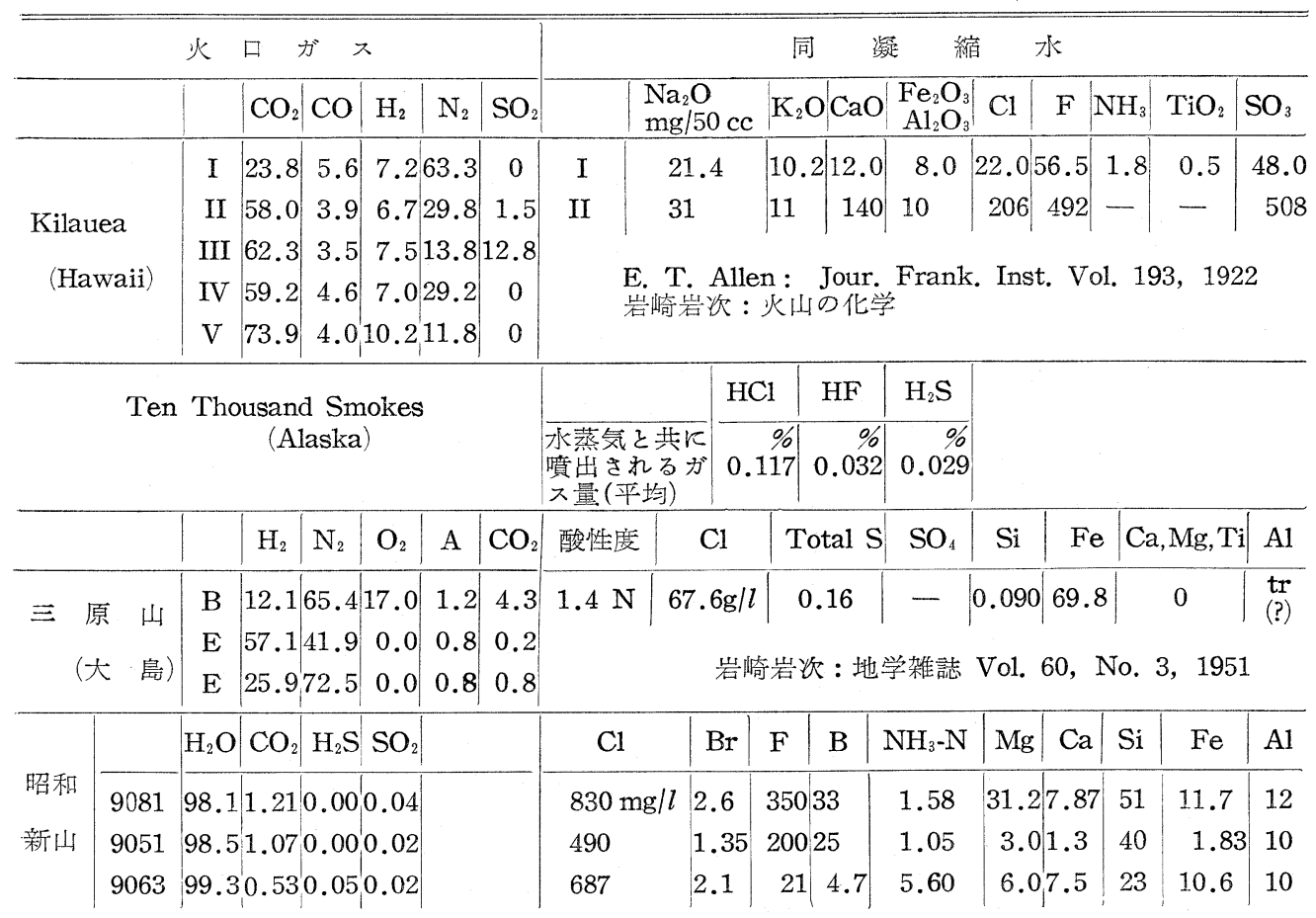

高橋博，小六進也：地質調查所報告 170 号，1957

は温泉水汇特ける $\mathrm{Cl}^{\prime}$ の消長という問題に相通ずるものでもある。すなわち, 後で述べるようと, 自然界 飞は $\mathrm{Cl}^{\prime}$ を含む温泉と $\mathrm{Cl}^{\prime}$ の極めて少ない温泉とが存在し，温泉水に和けるこのような $\mathrm{Cl}^{\prime}$ の消長もま た，たんに地下水による稀釈あるいは熱源の裏微ということだけによるのではなく，むしろ，地下水と接 もる火山性ガス自体の流動值接の繋りをるつとみなされるからである。この問題は，火山ガスないし噴 気ガスによつて生成された櫴気性温泉（招よび熱気性温泉*）の諸性質を考察する上に 極めて重要な内容を 含み，火山地带温泉に和ける最も基礎的な事柄の 1 つに数光られるものである。

（2）噴気地带化伴5温泉水の型

前項で述べたうに，自然界には $\mathrm{Cl}^{\prime}$ を含む温泉と， $\mathrm{Cl}^{\prime}$ 含量の極めて少ない温泉とがある。こつでね 火山ガスの流動に伴う $\mathrm{HCl}$ の消長という問題に関連して, 噴气地带に伴う温泉水の諸性質を取上げ, 温 泉水て少引る $\mathrm{Cl}^{\prime}$ の消長という問題を検討してみることにする。

火山地带温泉の中には，しばしば噴気地带の側面から湧出するものがある。これらの温泉は, 成因的に 火山ガスないし噴気ガスと密接な関連があることはいら迄もないが，い主との一例として，大分県飯田䯩 原大岳噴気地带に括ける噴気・温泉群 ${ }^{2}$ をとり上げ，变質带と噴気・温泉との分布関係を示すと，第 1 図 の通りである。図で示したように，この地域には現在，河原・大岳・小松の三蕡気地帯があり，その側面 飞当る地域から筋湯・疥痽湯等の温泉が湧出する。これらの噴気・温泉群は何れる现珠川本流および爷流 记沿了変質带に伴つて分布するが，兩者の関係をみると，より旧い時期に生成された変質带には $\mathrm{Cl}^{\prime}$ を含

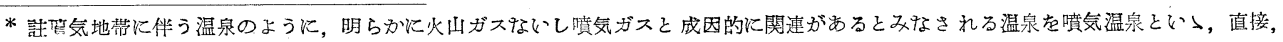

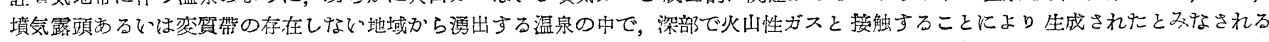
温泉を熱氧性温泉と呼んだ。 


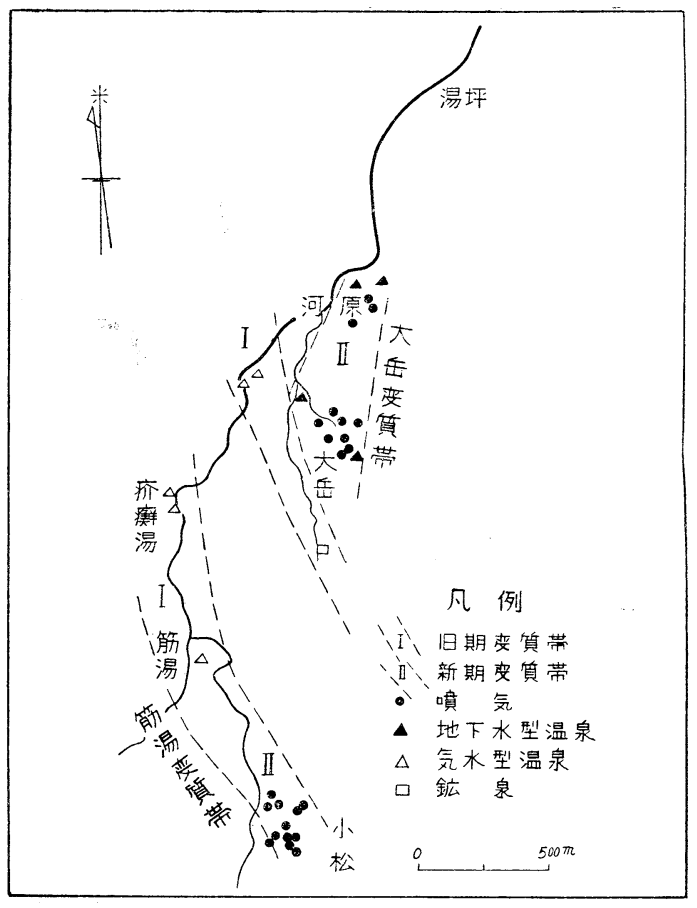

第 1 図大分県大岳附近の变資带，噴気，温泉分布図

む温泉が伴い，より新期の変質带には噴気およ び $\mathrm{Cl}^{\prime}$ の少ない温泉が存在する。この新旧何れ の变質带も過去より現在复る濆気作用によ つて生成されたもので，変質帯を追跡すると何 らかの原因により, 噴気活動が北から南, あるい は南から北へ漸次移行したことを示している。 このよ5に噴気の周辺から湧出する温泉が殆ど

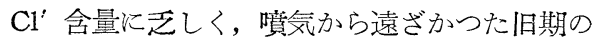
变質带に伴う温泉が $\mathrm{Cl}^{\prime}$ を含むことは，火山ガ スないし嘪気ガスと地下水との接触関係が，次 のような状態あることを暗示する。すなわち 地下水の渗透深度の差によつて, 地下水に供給 されるガス成分中の $\mathrm{HCl}$ の濃度が 㟟り，浅い 部分では，より $\mathrm{HCl}$ が少なく，深部では，よ り多くの $\mathrm{HCl}$ を含むということである。この ように考学ると, 前述べた噴気活動の移動 も，その原因が地下水の㴰透に関連があること が判る。すなわち, 時間の経過と共に, 外圧と して作用する地下水が，噴気ガスの蒸気圧を抑 光，その結果，噴気地带はより外圧の低い方向 へ移行し，同時に変質带もこれに伴つて移行し たと考觉られるのである。

このような，噴気地带に伴う温泉は， $\mathrm{Cl}^{\prime}$ を含むいわば気水型温泉 (Saline water type) と, $\mathrm{Cl}^{\prime}$ に泛 い地下水型温泉（Ground water type）とに分将られるが，この両者は火山地带に扔ける代表的な 2 つの 型を示するのである。勿論，場所によつてこの両者の間に明確な 境界を設けることの出来ない場合があ り，委た地域的に気水型温泉の $\mathrm{Cl}^{\prime}$ 含量がかなりの幅で変化することもある。噴気地带に伴う温泉が，い

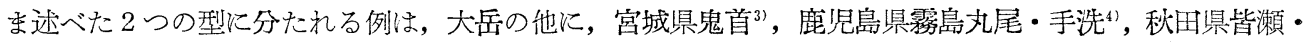

第 2 表 別府市南立石白竜噴気地带に扣ける天然蒸気の化学成分（容積）

\begin{tabular}{|c|c|c|c|c|c|c|}
\hline & 温 度 & $\mathrm{H}_{2} \mathrm{O}$ & $\mathrm{CO}_{2}$ & $\mathrm{H}_{2} \mathrm{~S}$ & $\mathrm{O}_{2}$ & $\mathrm{~N}_{2}$ \\
\hline 白竜錅井噴気 & $141^{\circ} \mathrm{C}$ & 98.75 & 1.17 & 0.0051 & 0.015 & 0.064 \\
\hline 実験用旧警井噴気 & $138^{\circ} \mathrm{C}$ & 98.77 & 1.22 & 0.0074 & 0.001 & 0.011 \\
\hline 自然噴 気 露 頭 & $98.2^{\circ} \mathrm{C}$ & 92.7 & \multicolumn{2}{|c|}{6.5} & & \\
\hline
\end{tabular}

同上地带に和ける天然蒸気凝縮水扣よび川水の化学成分 $(\mathrm{mg} / l)$

\begin{tabular}{|c|c|c|c|c|c|c|c|c|c|c|c|c|c|}
\hline & 温度 & $\mathrm{pH}$ & $\begin{array}{l}\text { アルカ } \\
\text { リ度 }\end{array}$ & $\mathrm{Cl}^{\prime}$ & $\mathrm{SO}_{4}{ }^{\prime \prime}$ & $\mathrm{HBO}_{2}$ & $\mathrm{~F}$ & $\mathrm{NH}_{4}{ }^{\circ}$ & $\left|\mathrm{CO}_{2}\right|$ & $\mathrm{H}_{2} \mathrm{~S}$ & $\mathrm{SO}_{2}$ & $\mathrm{SiO}_{2}$ & Ré \\
\hline 白竜鏊井噴気凝縮水 & $80^{\circ} \mathrm{C}$ & 7.1 & 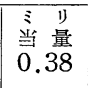 & $<0.2$ & 0 & 1 & $<0.1$ & 2.7 & 1 & 0.1 & 0 & 0 & 18 \\
\hline 実験用旧鈠井噴気 $" /$ & 86 & 7.2 & 0.36 & $<0.2$ & 0 & 1 & $<0.1$ & 2.8 & 1 & 0.2 & 0 & 0 & - \\
\hline 川 & 17.5 & 7.1 & 1.53 & 2.1 & 23 & 0.5 & - & 0 & 12 & 0 & - & 9.2 & 235 \\
\hline
\end{tabular}

分析 : 東京都立大 野口喜三雄, 上野精一 


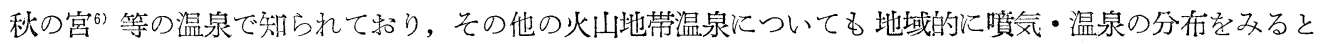
噴気地带の外側飞気水型温泉の分布する場合が少なくない。

いま述べた事柄の中で，何故温泉水が $\mathrm{Cl}^{\prime}$ 合量の上飞消長があるかという問題沉ついて，次のような考 え方も可能である。すなわち，既汇深部にいわゆる熱水と呼ばれる高温の温泉水があり，その一部が地表 近づき，外王が減少することによつて沸騰を始め，気化した蒸気が噴気地帯を形成し，また熱水の一部

(a) 万座型

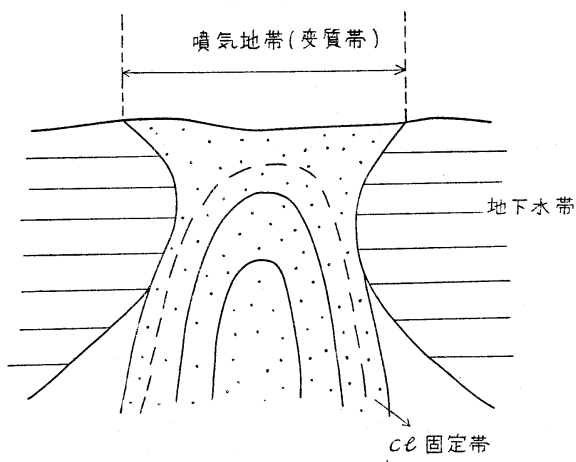

$\left(a^{\prime}\right)$

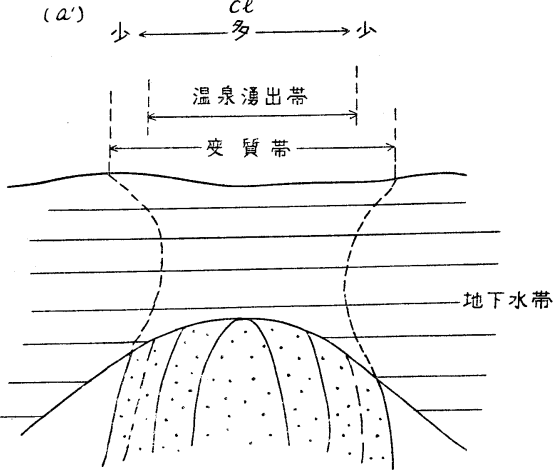

( 电) 效尾型

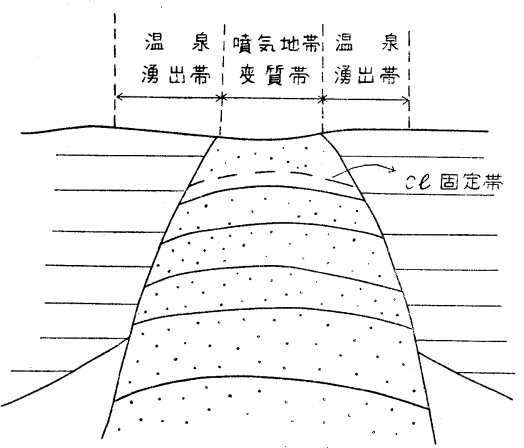

$\left(\mathfrak{f}^{\prime}\right)$

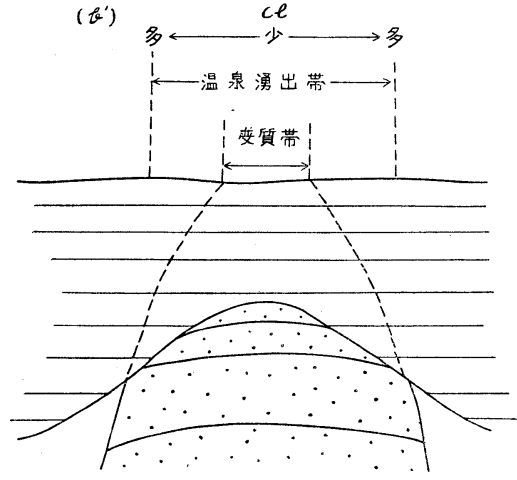

第 2 図喷気ガスと地下水との関係を示す模式断面図

が気水型温泉として噴気地带の側面から涌出するという場合である。地域汇よつてこのような機構で， 2 次的汇発生した蒸気が存在するところもあるが，初生的な火山ガスの存在，火山ガスと噴気ガスの間に

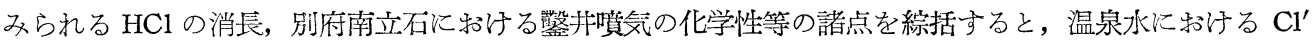
の消長は, 本質的に火山ガスないし噴気ガスの流動と，それに接する地下水の溜透深度の両面に 最る深い

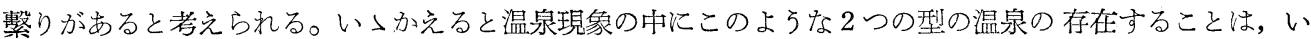
わ゙゙噴気ないし熱気から導かれた噴気性ないし熱気性温泉にのみ見られる現象であるといえよう。従つ 
て，この問題を発展させて行くと，たとえ地表に噴気あるいは变質帯の存在しない地域から汿出する温泉

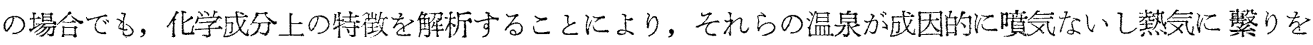
もつかどうかの判断に，理論的な根抛を与えることになる。この問題のもつ意味は，火山地方のみなら ず，他の火山岩地带の温泉についても，その地域性を考劣る場合の基礎として，重要な内容を含んでいる とみなされるのである。

(3) $\mathrm{Cl}^{\prime}$ 固定带の設定

前項で述べたように噴気地带に伴う温泉は気水型温泉と地下水型温泉とに分たれるが，一方，地域的な 噴気，温泉の分布の上から地带別に分けてみると，嘪気地带と温泉地带とに区別される。

こ〉で噴気地带というのは，噴気抢よび地下水型温泉の存在する地域であつて，地表あるいは地表近く に火山ガスないし噴気ガスが接近している地带をい〉，温泉地帯というのは，難揮発悴の塩化物を含む気 水型温泉の汿出地带である。

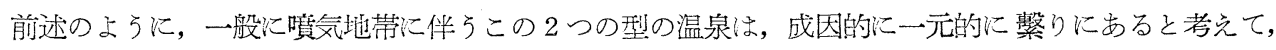

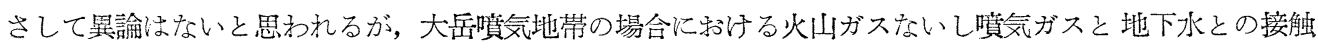

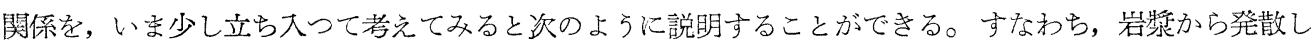
た揮発成分が，深部まで㑢透した地下水に吸收され，水蒸気の㠜縮に伴う潜熱を発生すると同時に，この 潜熱彷よて加温された地下水法 $\mathrm{HCl}$ を始めいわゆるガス成分を 溶解して酸恎となる。遊離璼酸 $(\mathrm{HCl})$ を含む強酸性地下水は，酸柱のま〉涌出するか，昰たは涌出の過程で接触する岩層によつて中和され，い わゆる気水型温泉の性質を带びるようになる。このように，気水型温泉の生成には，火山ガスを発散する 火山性エマネーションと，そのガス成分を吸收するまで梁部に泫透した相当量の地下水の存在を前提とす る。そしてさらに, 両者の関係については, 深部まで唀して地下水と, より梁部からのエマネーション とがある面で熱力学的な平衡を保ち, その状態で地下水中に $\mathrm{HCl}$ 等の強酸性ガスが供給されると考劣ら れる。このような状態市るとすれば, 噴気地带は, 相対的に外圧の低い地域であるということができ, 従つて，噴気地带の形成が外圧としての地下水が少ないことを条件とするのであれば，岩漿からのエマネ ーションの中に含まれる $\mathrm{HCl}$ はその上昇過程で直接, 地下水に吸收される機会より, むしろエマネーシ ョンによる箚化学的な因子として接触する岩層㑮き, 蒸気(あるいは気相) 圈内であっても, 難揮発性の 盖化物として固定される篦である。すなわち，噴気あるいは地下水型温泉を伴う噴気地带では，ある深さ にいわば $\mathrm{Cl}^{\prime}$ 固定带とでもいつうるもの>存在が想定されるのである。

この上う教える，この $\mathrm{Cl}^{\prime}$ 固定带の上部て噴気ガスが地下水を加温して生成されたのが地下水型温 泉であり，地下水型温泉を生成した地下水がさらに梁く滲透し，蒸気圈内の範囲を狭めつ〉， $\mathrm{Cl}^{\prime}$ 固定带 より下部に達すると，成分的に気水型温泉の特徵を帯びるょうになると考えることができる。

$\mathrm{Cl}^{\prime}$ 固定带の設定は，嘖気ガス自体の流動と，それに伴うガス成分の 固定といら概侴で導かれたものて あるから，このような考方方を基礎として，火山地带温泉を取坡つてみると，特に地域的な温泉水の分布 は，噴気ガス之地下水々の相対的な接触関係，劣るいは噴気ガス自体の存在状態を反映する意味で，火山 地带温泉の地域性を解析する場合の手掛りとして重要な役割を集すことになる。

この固定された $\mathrm{Cl}^{\prime}$ がそのま〉監類の形で变質帯の中に保存されるものか, あるいは地下水によつて洗 い流されてし至うものかという点については，まだ十分明かでない。然し，噴気地带に伴う温泉の生成が 嘪気ガスと地下水との熱力学的な平衡状態に関連あるものとすれば，たと光固定された $\mathrm{Cl}^{\prime}$ が変質带の中 に篮類の形で残留している場合でも，結局，より深くをで㑢透した地下水によつて洗い流されてしまう可

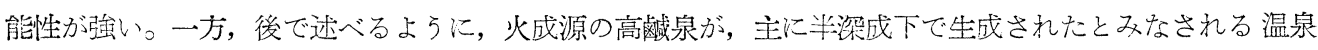
あるいは鈗泉に限られるという点を考えると，生成環境の差によつて固定された $\mathrm{Cl}^{\prime}$ が，長く岩層中浑 留される場合もありうることを示しており， $\mathrm{Cl}^{\prime}$ 固定带設定の意義は，噴気の 流動性を反腫するという点 だけ留要らず，温泉の成因を系統的に分類する上の手脚りとして，極めて注目に值する事柄を代表して 
いるとみなされるのである。

(4) $\mathrm{Cl}^{\prime}$ 含量の分布とその規䋶性

火山地方の変質带は, 殆どいわをる噴気作朋とそれに伴う温泉水によつて生成されたものが大部分を占 める。噴気地带に伴う温泉水が 2 つ型で代表されることについては既に述べた通りであるが，一般に变 質帯に伴う温泉水の含量の分布をみると，次の 2 つの形式に分たれることに気がつく。すなわち，1つは 中心ほど $\mathrm{Cl}^{\prime}$ 含量が高く，外側に移るほどとの舍量が聥減する場合であり，他の 1 つは中心ほど逆に $\mathrm{Cl}$ ， 含量が低く，外側ほどむしろ含量が増大する場合である。温泉水の $\mathrm{Cl}^{\prime}$ 含量の分布の上にあらわれたこの ような相違が，地下水と火山ガスないし噴気ガスとの接触関係に繁りをもつことについては，噴気地带に 伴う温泉水の諸性質から容易に推定されるところである。前者の例は，火山地帯温泉の中で， $\mathrm{Cl}^{\prime}$ 含量の 高い酸性泉の場合が多く, 群馬県万座 ${ }^{61}$ を始め, 同県草津, 秋田県玉川, 青森県宇既利恐山, 大分県海老 野 ${ }^{7}$ 等の温泉がこれに相当する。後者の型は, 現在な括噴気地带を形成する地域に多くみられ, 鹿児島県 霧島丸尾，宮城県鬼首，大分県大岳等を挙げることができる。 $\mathrm{Cl}^{\prime}$ 含量分布の上にあらわれるこの規則性 は，たんに温泉水が地下水によつて機械的て稀翻されるということだけではなく，本質的には温泉化作用* に打ける噴気ガスの流動とそれに作用する外圧との関連によるものと考えられる。

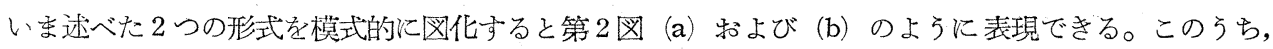
(a) は火山ガスないし噴気ガスの流動速度が大で，しかも蒸気圧が地下水より卓越した場合である。この 場合は両者の圧力の平衡関係から蒸気带と地下水帯との接触面を追跡すると, 蒸気带の形態は, 地下水带 に大つてから茸状に上に拡つた形式をとると考えられる。これに対して (b) は比較的割目が少ないため, 噴気ガスの流動速度が小さい場合を示したものであるが，この場合は，たとえ蒸気圧が地下水圧より大で あつても, 岩圧が働くため地下水帯と蒸気帯との接触面は上方に進むにつれて狭くなる傾向をもつ。

賴気ガスの流動は, 結局, 蒸気圧と外圧との 圧力差によるるのであるから, 噴気ガスに含まれる $\mathrm{HCl}$ の等濃度線あるいは $\mathrm{Cl}^{\prime}$ 、固定帯の形態は，噴気ガスの流動速度に支配され，(a) では流動速度に平行する が，(b) では逆に流動方向と交叉する方向に漸次 $\mathrm{HCl}$ の濃度が稀薄になるのが特徴的である。

い述べた 2 つの型は，噴気ガスの行動を示す最も基本的な形態であるが，同時にこの型の生成如何 は，地域的な地質状沉に関速があるようにみえる。すなわち，(a) は節理，裂鐻，間隙等の発達した地域 に附随する現象であり，(b) は比較的割目の少ない岩層に被われた地域にみられるのが一般である。見掛

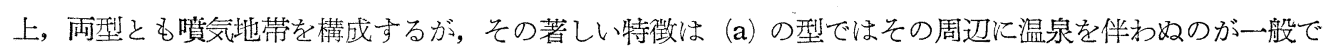
あり，(b) の地帯では噴気地帯の周辺から温泉が湧出するのが普通である。

また，変質带の構成という面からみると，(a) は中心より外側に向つて変質の程度が徽弱になるのに対 して，(b) の地带ではむしろ層状に変質の度合を变えて行く傾向がみえる。群馬県万座温泉 ${ }^{6)}$ に技ける変 質带の分布は (a) に相当するものであり，岩手県松川 ${ }^{8)}$ 和よびニュージランドのワイラケイ地方 ${ }^{9}$ ではむ しろ (b) の型に属する変質带の構成を示している。

いま述べた（a）（b）両型の噴気地带が，さらに時間の経過に伴い地下水の影響をうけ，噴気地带から 温泉地带へ移行した場合の状態を示したのが第2図 (a)' および (b)'である。(a)'では中心ほど $\mathrm{Cl}^{\prime}$ 含 量が高く, 外側に移るほど $\mathrm{Cl}^{\prime}$ が聥減するのに対して，(b)'では中心ほど $\mathrm{Cl}^{\prime}$ が少なく，外側ほぞ逆に $\mathrm{Cl}^{\prime}$ が增大する。前者の例はすでに述べた恐山, 万座, 立山を始め $\mathrm{Cl}^{\prime}$ 舍量の高い酸性泉がこれである。 また, 一般の温泉地带でも伊豆修善寺, 吉奈, 湯ケ島101等の中心ほど $\mathrm{Cl}^{\prime}$ 含量の高い温泉は, 本質的に (b)' の型と同じ性質のものと考支られ, 伊豆古奈長岡温泉间のよ5に外側に移るほど $\mathrm{Cl}^{\prime}$ 含量が増加し, かつ温泉の分布範团の広い地带は，(b)' の型をあらわすものとみることができる。

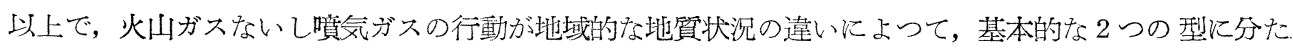

\footnotetext{
*註 地下水が火山性ガスと接触することによつて温泉化する作用を指す。
} 
れ，乙かもその各々の型は，温泉水の $\mathrm{Cl}^{\prime}$ 含量の分布に規則恔を与兄ることについて述べた。噴気地带沉 括ける 2 つの型の存在は, 火山地帯温泉の基礎として重要な意味をもち, 変質带をもたぬ一般の温泉につ いても， $\mathrm{Cl}^{\prime}$ の分布と地質構造との間関連のあることを示して敊り，火山地带温泉の地域性関する事

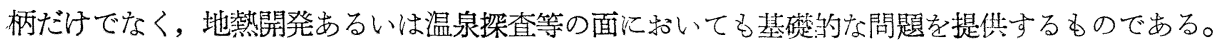

\section{2 , 地域的な温泉水の化学性}

火山地带温泉がその存在する場所の違いよつて，ぞのような化学成分の相違を示すかという問題は，い わば火山地带温泉の地域性に繫る大きな課題の 1 つである。勿論, この地域㥄の問題は, たんに化学的性

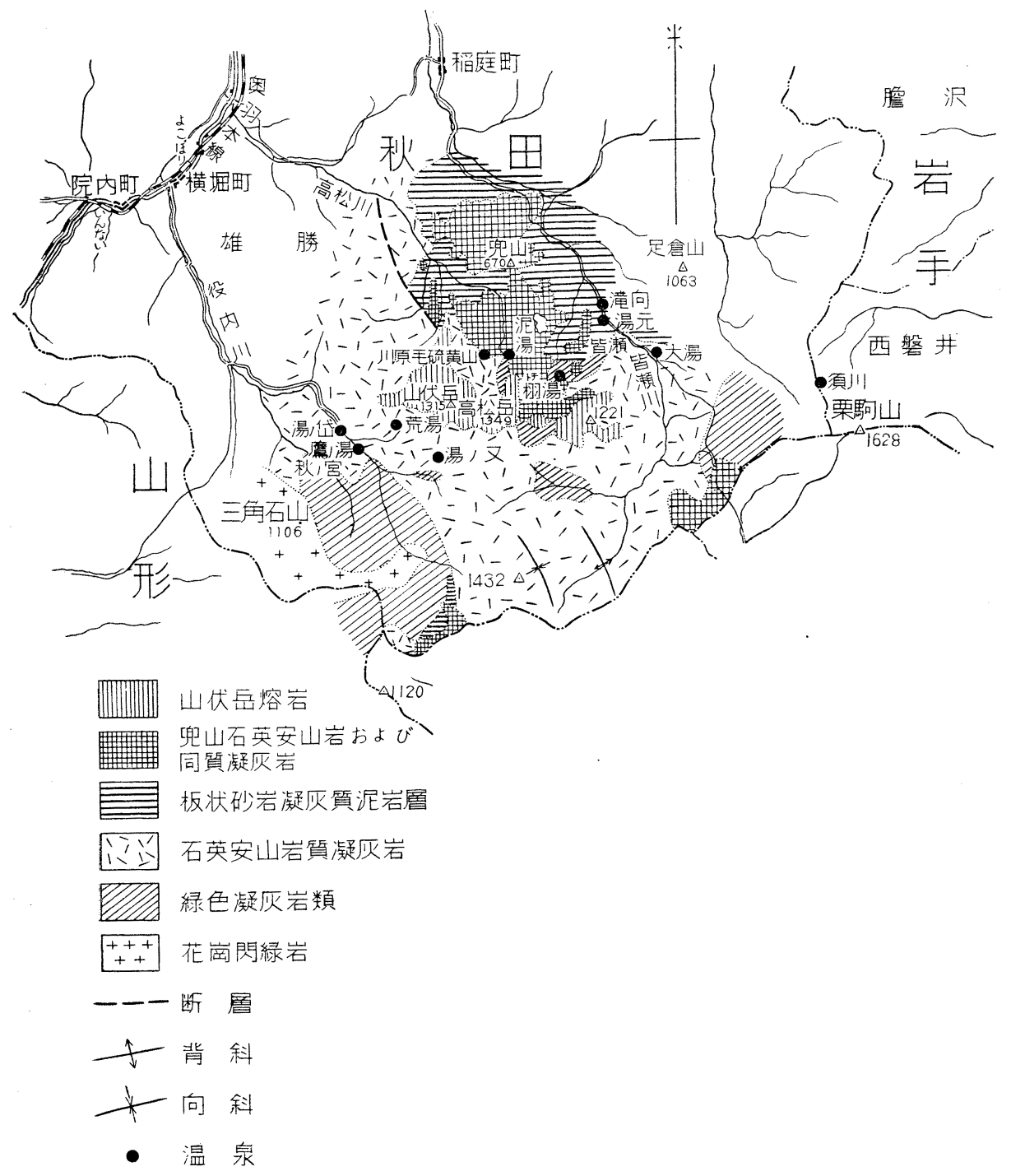

第3図秋田県秋の宮・皆濑温泉分布图 


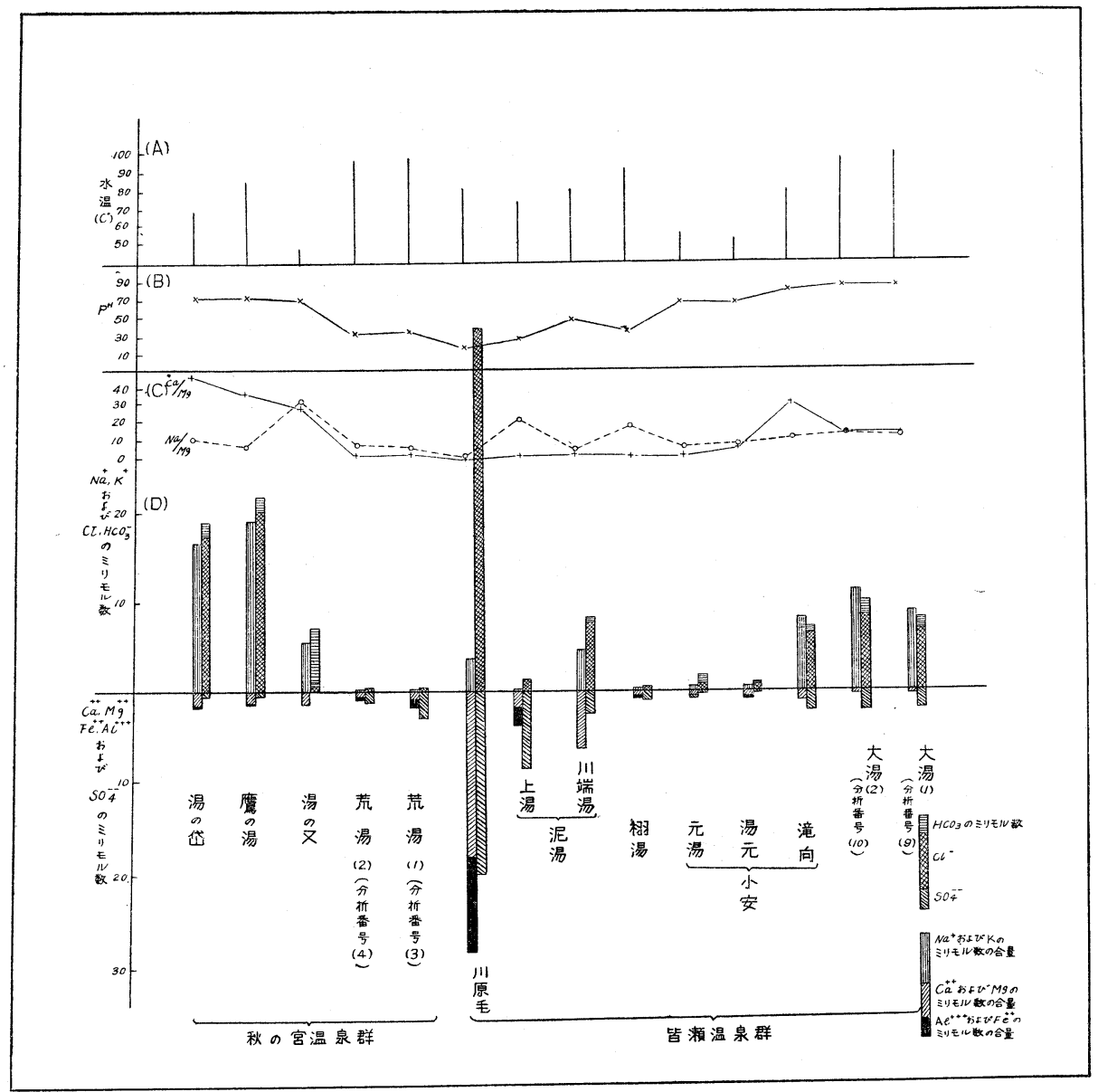

第 4 因秋田县秋の它・皆濑温泉群ミリ当量数此較図

質の面だけでなく, この化学性に熬りをもつ構造的な要素も含をれることはいう迄もない。構造的な問題 については，他の機会に取りあげる予定にしているので，こ〉では，火山地帯温泉の中から代表的な 2,3 の例を選び，地域的な化学性の变化を検討してみることにする。

な扔，冒頭で触れたよに，火山地带温泉といつても，その存在する場所によつて，化学性は比較的多 様である。然し, この問題は, 結局, 噴気ガスと地下水との相対的な接触関係によつて支配されるもので あり, 特に, 温泉水に扝ける $\mathrm{Cl}^{\prime}$ の量的な变化は，この問題の解析に極めて大きな役割を果するのであ

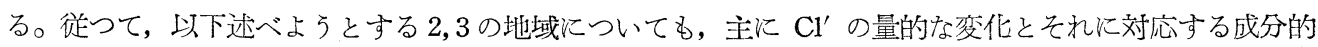
特徵に焦点をしぼり，地域的な温泉水の化学性の問題沈触れてみることにする。

第 3 㘡は, 秋田県雄勝地方に所在する秋の宮拈よび皆瀬温泉群の分布を示したものである。この図から

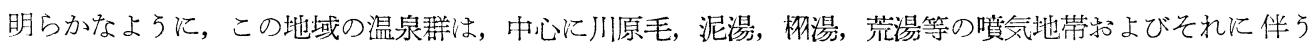
温泉があり，その外側江鷹の湯，湯の黛，小安，大湯等の温泉地带がある。地域的に，これらの温泉がい かなる性質をもつかという点を検討するため，中心から外側に向つて成分相互の関係を比較すると第 4 园 および第 3 表の通りである。 
第 3 表 秋田県秋の宮・皆瀬温泉群化学成分表 (単位 $\mathrm{mg} / \mathrm{l}$ ) 分析 : 前田憲二郎

\begin{tabular}{|c|c|c|c|c|c|c|c|c|c|c|c|c|c|c|c|}
\hline & & {$\left[\begin{array}{l}\text { 水温 } \\
\left({ }^{\circ} \mathrm{C}\right)\end{array}\right.$} & $\mathrm{pH}$ & $\mathrm{H}_{2} \mathrm{~S}$ & $\mathrm{Cl}^{\prime}$ & $\mathrm{SO}_{4}{ }^{\prime \prime}$ & $\mid \begin{array}{c}* \mathrm{M} . \mathrm{Or} \\
\text { ル リ度 } \\
\vdots \text { リ } \\
\text { 量/l }\end{array}$ & $\mathrm{Na}^{\circ}$ & $\mathrm{K}^{\bullet}$ & $\mathrm{Ca}^{*}$ & $\mathrm{Mg}^{*}$ & $\mathrm{~A} 1 \cdots$ & $\mathrm{Fe}^{\cdot}$ & $\mathrm{Fe}^{\cdots}$ & $\mathrm{H}_{2} \mathrm{SiO}_{3}$ \\
\hline \multirow{5}{*}{$\begin{array}{l}\text { 秋 } \\
\text { の } \\
\text { 宫 } \\
\text { 温 } \\
\text { 泉 } \\
\text { 群 }\end{array}$} & 鷹 の 湯 & 84 & 7.2 & 1.1 & 718.1 & 24.7 & 1.60 & 407.2 & 48.1 & 25.1 & 0.7 & 1.0 & 1.5 & 0 & 162.5 \\
\hline & 湯 の岱 & 70 & 7.2 & 0.5 & 622.3 & 23.9 & 1.20 & 366.3 & 32.2 & 32.2 & 0.7 & 1.0 & 1.5 & 0 & 114.4 \\
\hline & 荒 湯 (1) & 97 & 3.2 & 1.0 & 16.0 & 151.4 & 一 & 4.3 & 0.8 & 9.1 & 3.3 & 3.0 & 13.0 & 0 & 89.7 \\
\hline & $\prime \prime \quad(2)$ & 95 & 3.0 & 1.0 & 16.0 & 54.3 & - & 3.9 & 0.5 & 6.0 & 2.2 & 0.2 & 0.6 & 0 & 45.5 \\
\hline & 湯 の 文 & 47 & 6.8 & 0.8 & 16.0 & 0.1 & 6.53 & 127.1 & 3.9 & 26.1 & 0.9 & 0.8 & 32.5 & 5 & 159.9 \\
\hline \multirow{3}{*}{ 皆 } & 小安滝向 & 80 & 8.0 & 2.0 & 213.7 & 107.8 & 1.12 & 151.5 & 13.2 & 21.1 & 0.7 & 0.5 & 1.5 & 0 & $2\lfloor 3.2$ \\
\hline & "l 元湯 & 60 & 6.6 & 3.4 & 33.7 & 15.6 & 0.92 & 13.8 & 2.4 & 9.1 & 0.7 & 1.5 & 5.0 & 0 & 15.6 \\
\hline & "l 湯元 & 54 & 6.5 & 0.8 & 16.0 & 11.5 & 0.30 & 13.8 & 2.4 & 7.0 & 1.1 & 1.5 & 5.0 & 0 & 16.9 \\
\hline \multirow{2}{*}{$\begin{array}{l}\text { 瀬 } \\
\text { 淐 }\end{array}$} & 大 湯 (1) & 100 & 8.4 & 8.7 & 222.5 & 106.2 & 1.80 & 190.8 & 14.8 & 8.0 & 0.7 & 0.6 & 1.3 & 0 & 254.8 \\
\hline & $\prime \prime \quad(2)$ & 99 & 8.6 & 4.1 & 301.4 & 143.2 & 1.40 & 247.4 & 19.1 & 9.0 & 0.7 & 0.5 & 5.0 & 0 & 425.1 \\
\hline \multirow{4}{*}{ 泉 } & 椅 & 92 & 3.2 & 1.5 & 14.2 & 44.4 & 一 & 5.5 & 0.2 & 5.0 & 3.1 & 1.3 & 6.0 & 0 & 16.9 \\
\hline & $\begin{array}{l}\text { 泥 晹 } \\
\text { (川端湯) }\end{array}$ & 99 & 4.5 & .1 & 273.9 & 128.4 & - & 93.2 & 20.9 & 58.3 & 34.3 & 2.5 & 3.0 & 0 & 157.3 \\
\hline & "l (上湯) & 74 & 2.3 & 0.5 & 44.3 & 415.6 & - & 7.4 & 0.2 & 17.1 & 10.3 & 8.4 & 26.0 & 0 & 167.7 \\
\hline & 川 原 毛 & 92 & 1.2 & 0.5 & 1296.9 & 957.2 & - & 62.2 & 45.2 & 134.7 & 137.0 & 100.6 & 72.6 & 0 & 330.2 \\
\hline
\end{tabular}

第 4 図から明らかなように, 中心から外側へ向つて温泉水の液性は酸性から中性ないしアルカリ性に変 化する。次に, 各成分の分析值をミリモル数汇換算し, 各々の温泉に括ける量的な関倸を比較してみる と, 第 4 圀(D) のようになる。この図をみて, 先づ注目を引くのは川原毛湧泉についで゙ある。この湧泉 は $\mathrm{pH} 1.2$ という強酸性であり, 著量の $\mathrm{Cl}^{\prime}$ そ $\mathrm{SO}_{4}{ }^{\prime \prime}$ で特徵づけられる。そして, 陽イオンのミリモル 数の合計が $\mathrm{Cl}^{\prime}$ だけのミリモル数に及ばないことから判断して, 川原毛の温泉は初生的に遊離塩酸拉よび 硫酸を含有するとみなすことができる。いかか光ると，川原毛の強酸性泉は地下水が，地下浅所で $\mathrm{HCl}$ および $\mathrm{SO}_{2}$ などを含むいわゆる火山ガスと接触し，水中に溶解した $\mathrm{HCl}$ および $\mathrm{H}_{2} \mathrm{SO}_{4}$ がな和，中和さ れるに至らぬうちに湧出したものである。この種の温泉は, 火山地帯温泉の多い我国でも例が少なく, 僅 か秋田県玉川 ${ }^{111}$, 富山県立山地獄谷等で知られているに過ぎない。このよ5に, 川原毛温泉は, その生

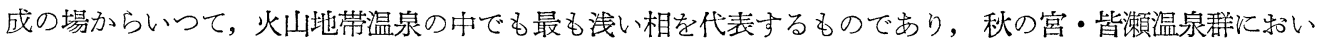
ても火山作用の中心地域㑑当することを示している。

前述の上万に, 川原毛涌泉に特ける特徵は, $\mathrm{Cl}^{\prime}$ に対してアルカリメタルのミリモル数が極めて少ない ことである。これに類する型は, 泥湯, 鷹の湯, 湯の岱等であり, これに対して小安滝向, 大湯等では全 〈対蹠的にむしろ $\mathrm{Cl}^{\prime}$ に対するアルカリメタルのミリモル数が遥かに過剩な值を示す。

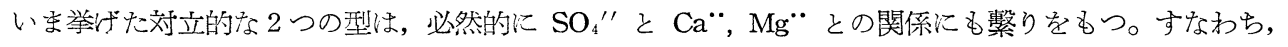
前者の型は $\mathrm{SO}_{4}{ }^{\prime \prime}$ のミリモル数に対して, $\mathrm{Ca} \cdot, \mathrm{Mg}^{\circ} \cdot \mathrm{Al}$ ”等の合計が滛かに過剩であり, 後者では逆に $\mathrm{SO}_{4}{ }^{*}$ のそれより低い值を示している。

温泉水の間でみられるこの 2 つの型がいかなる原因によるかという問題に 関連して, 先づ考えられるこ とは初生的な温泉水の酸性度の問題である。川原毛の湧泉が盐酸と酸であることは既汇述べたが, 各温泉 に怙ける初生的な酸性度も川原毛の場合と同じ上弓に, 深部で火山ガスと接触し温泉化した地下水中の $\mathrm{HCl}$ の濃度によつて吝配されるものと思われる。このよ5に考光ると, 泥湯の川端湯, 鷹の湯, 湯の岱等

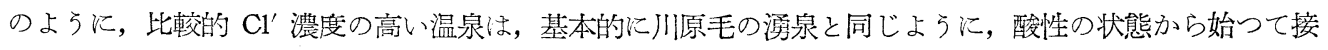


触岩層から岩石成分を溶出させ，各々類似の進化系統を辿つて涌出したと考兄られる。勿論，現在，涌出 口で測定される $\mathrm{pH}$ の值は初生的な温泉水のそれではなく, 温泉化した地下水が地表へ涌出する迄の距離 と時間によつて異る。すなわち，その温泉水がな和， $\mathrm{HCl}$ 特よび $\mathrm{H}_{2} \mathrm{SO}_{4}$ を含むか，これらの強酸が中和 され $\mathrm{CO}_{2}$ の溶存と $\mathrm{HCO}_{3}{ }^{\prime}$ の生成が許される状態にあるか, むるいはおた, さらに進化して $\mathrm{CO}_{2}$ 方全 く $\mathrm{HCO}_{3}{ }^{\prime}$ 飞置き換えられるかによつて, 液性も酸性から中憔抢よびアルカリ性の方へ動くことになる。 泥湯，鷹の湯，湯の岱等に和ける $\mathrm{pH}$ は，現在 $\mathrm{CO}_{2}$ を溶存することによるるのである。

一方，小安滰向扰よび大湯に括斿る陰，陽イオンの量的な関係をみると，上述の各温泉とは異り，明ら かに $\mathrm{Cl}^{\prime}$ に䞑してアルカリメタルのミリモル数が過剩である。なぜこのような状態をとるかという点につ いては，一応次のように考えることができる。すなわち，前者の諸温泉に比へ，これらの温泉の $\mathrm{Cl}^{\prime}$ 合量 が比較的少ないことから推察すると，深部で温泉化した地下水の酸性度は比較的低く，このため地表へ涌 出する迄の間に, 前者より相対的に結合関倸がさらに進化した状態をとるということである。事寒, 温泉 の液性はアルカリ性であり，硫化物の一部は水硫化物の形をとつて溶存する。そしてこの場合 $\mathrm{HS}^{\prime}$ は一 般にアルカリメタルと結合しやすい傾向があるので，第4困の（D）をみても，㜔向，大湯では $\mathrm{SO}_{4}{ }^{\prime \prime} の$ 舍量に比べ, $\mathrm{Ca}$ “, $\mathrm{Mg}^{*}$ のミりモル数が比較的小さく, 結果的に $\mathrm{SO}_{4}{ }^{\prime \prime}$ の増大に伴い, アルカリメタル もまた増加を来したことが判る。い小かえると，滰向，大湯に括ける $\mathrm{SO}_{4}{ }^{\prime \prime}$ 打よびアルカリメタルの堌加 は，アルカリメタルの水硫化物が地表近くて酸化され，2次的に水硫化物がアルカリメタルの硫酸塩に变 り，総体的にみて， $\mathrm{Cl}^{\prime}$ に対してアルカリメタルのミリモル数が過剩となつたと解釈されるのである。

以上述べたのが秋の宮・㫮瀨温泉群の概略であるが，その諸性質を綜括すると，次のように要約でき

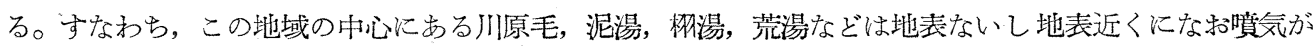
存在し，噴気地带に伴う温泉のみならず，その外側にある鷹の湯，湯の岱，湯の又，大湯，小安等の温泉 地带に执いても，温泉水の諸㤬質が，地下水と潜在噴気との相対的な深度差に関連をもつことによつて， 地域的に火山地带温泉としての体系を整光ているといらことである。

秋の宮・皆瀨温泉群の実例は，一地域内に遊離塩酸を含む強酸性の温泉に始つて，アルカリ性の温泉ま で存在する多㥞な温泉水の相互関係を示している。然し，地域的にな沶，次のような化学性をもつ温泉が

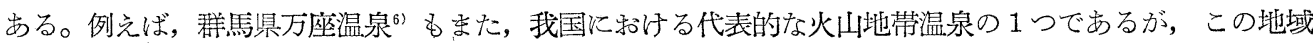
の温泉水は，かなりアルカリメタルの量が多いが(第 5 図)，液性はなお $\mathrm{pH} 1.7$ という酸性である。すな

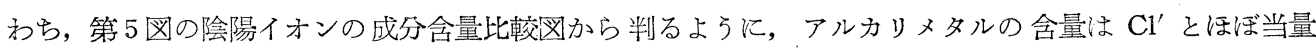
か，あるいはむしろ過剩の傾向岕り，川原毛の場合に比ベアルカリメタルの含量が著しく増大している ことを示している。な抗この地域は，中心ほど $\mathrm{Cl}^{\prime}$ 含量が高く，側方に移るほど含量が聥減する典型的な

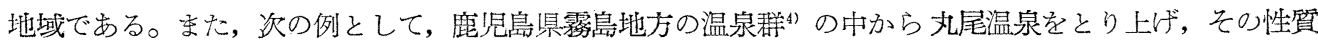
を述べると次の通りである。霧島地方に抢ける嘪気・温泉の分布は，かなり広い範团を占めて拉り，丸尾 温泉はその一部であるが，こ〉輴気・温泉の共存地域であつて，変質带の中心噴気露頭があり，その 外縁に温泉が存在する。温泉水の化学成分をみると極めて $\mathrm{Cl}^{\prime}$ 含量の少ないるのが中心近くにあり，外方 に向うほど $\mathrm{Cl}^{\prime}$ 舍量が増大し，同時に $\mathrm{Cl}^{\prime}$ と $\mathrm{HCO}_{3}{ }^{\prime}$ との間に負の相関々係がある。この地域の温泉は $\mathrm{pH}$ 6.3 7.9 の間にあり， $\mathrm{HCl}$ 扔よび $\mathrm{H}_{2} \mathrm{SO}_{4}$ は何れる中和され， $\mathrm{pH}$ に影響を与える因子は $\mathrm{CO}_{2}$ の溶 存によるものである。いつかえると，同じ变質带の中から涌出する温泉でもこの地域の温泉は，殆で遊影 強酸を合まず，從つて温泉水中に $\mathrm{CO}_{2}$ 肪よび $\mathrm{HCO}_{3}{ }^{\prime}$ の溶存を許すほど前二者に比べ，さらに進化した 状態淿あるとを物語つている。

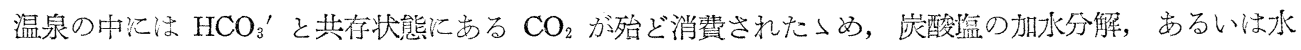

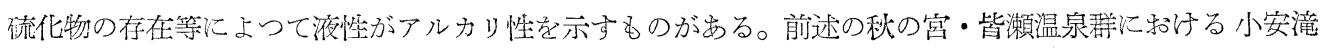
向, 大湯温泉はこの例飞相当する温泉であって, 分布の上からみると, このアルカリ性の温泉は分布地域 の最も外側汇位置を占る場合が多い。 


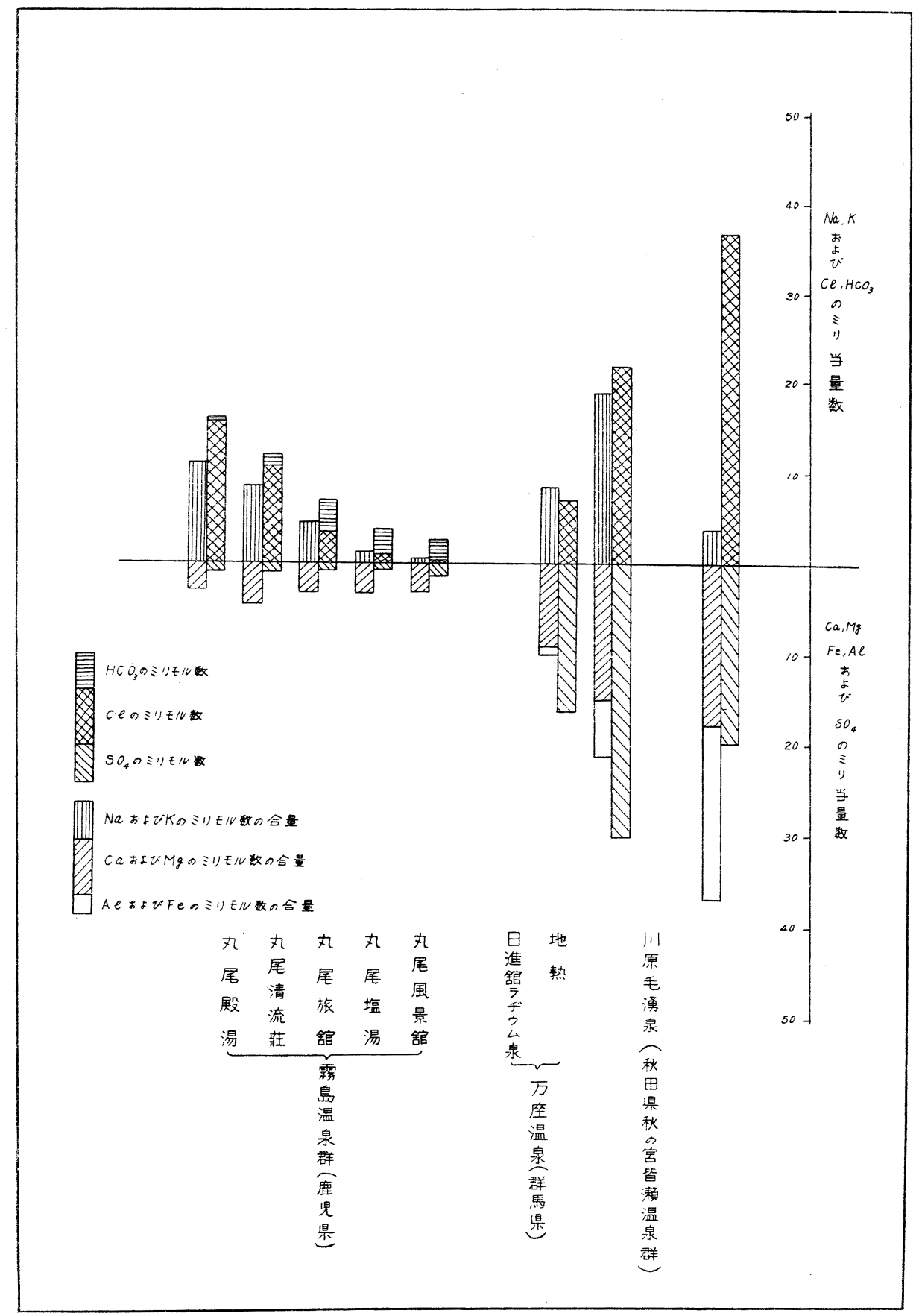

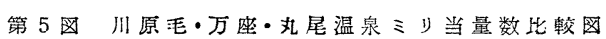


上で挙げた幾つかの例は，火山地帯温泉の中で特に变質带を伴うものડ中から選び出した例であるが， いま説明したように同じ変質带に伴う温泉水の場合でも，場所によつて比較的多様な化学性を示してい る。然し, 系統的汇温泉水の成分変化を組立て〉みると, この化学成分の多椂性は, 結局, 火山ガスない 乙噴気がスの流動状態と，それに接する地下水の相詨的な缷透梁度に 関連があり，さらにいわゆる熱源の 梁さという要素が，いわゆる火山㥄エマネーションの化学性に大きな影響を与えていることを知る。火山 活動の生じる深さという面からみると，火山地带はいわば最も浅い場を代表するものであり，従つて，火 山地带温泉の地域性も, 結局, この浅い爇源の存在で支配され, 比較的多様な化学性で特徽づけられると みなされるのである。

\section{総括}

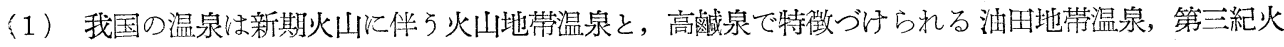
山岩抒上び半深成岩地带温泉, 花崗岩地带温泉

（2）火山地带温泉の地域性を考察するための基礎として，次の幾つかの項目をあげることができる。 すなわち (i) 火山ガスと噴気ガスの成分的相違 (ii) 噴気地带に伴う温泉水の型 (iii) 温泉化作用注 ける $\mathrm{Cl}^{\prime}$ 固定带の設定 (iv) 温泉水の $\mathrm{Cl}^{\prime}$ 含量とその規則性等である。

（3）先づ火山ガスと唄気ガスとの間でみられる成分的相違であるが，一般に火山ガスは塩化水素 $(\mathrm{HCl})$ の存在で特徽づけられ，これに対して噴気ガスは硫化水素 $\left(\mathrm{H}_{2} \mathrm{~S}\right)$, 炭酸ガス $\left(\mathrm{CO}_{2}\right)$ 等の弱酸性のガス成分を 主体とする。この両ガス成分に和ける $\mathrm{HCl}$ の消長は, 火山ガスの流動によるものであり，この関係は， 温泉水に扮汓る $\mathrm{Cl}^{\prime}$ の消長といら問題にも関連がある。

（4）噴気地帯汇伴5温泉水汇は， $\mathrm{Cl}^{\prime}$ 含量に之しいものと $\mathrm{Cl}$ 含量で特徴づけられるものとの 2 つの 型がある。（3）で述べた現象にも関連して，噴気地帯に和ける 2 つ型の存在は火山ガスないし噴気ガス の流動と，それに接する地下水の渗透深度の違いに繋りがある。

（5）噴気地帯に伴５温泉に，上述の 2 つの型が存在するのであれば，岩漿からのエマネーションの中 に含まれる $\mathrm{HCl}$ は，その上昇過程で，直接地下水に吸收されるだけでなく，熱化学的因子として接触す る岩層に働き，蒸気あるいは気相圈内であつても難揮発性の瑥化物として固定される篔である。すなわ ち，噴合地带のある深さに，いわば $\mathrm{Cl}^{\prime}$ 固定带とい〉5るもの>存在が設定される所以である。

（6）変質带に伴亏温泉水の $\mathrm{Cl}^{\prime}$ 含量の分布には 2 つの型式がある。1つは中心ほど $\mathrm{Cl}^{\prime}$ 含量が高く，

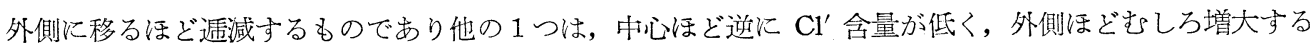
場合である。この現象は，火山ガスないし噴気ガスとそれに作用する外圧との関連によるものとみなされ るが，その何れの型をとるかてついては，その地域の地質状沉にも繫りがある。すなわち，前者は，節 理, 裂鏬等の発達した地域に附随するのに対して, 後者に比較的割目の少ない岩層に被われた地域にみら れるのが一般である。な特, 变質带の構成という面からみると, 前者では中心より外側に向つて変質の程 度が微弱になるのに対して, 後者の地域では，むしろ層状に变質の度合を変えて行く傾向がある。

（7）火山地带の地域的な温泉水の化学性を示す例として, 秋田県秋の宫・皆瀬温泉群の場合をあげた

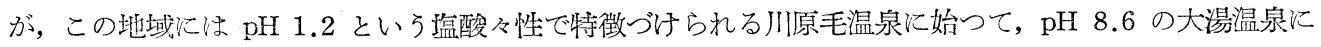
至るまでの多様な温泉が存在する。然し, 系統的温泉水の成分変化を組み立てつみると, この化学成分 の多様悎は, 結局, 火山ガスないし噴気ガスの流動状態と, それに接する地下水の遪透深度に関連があ

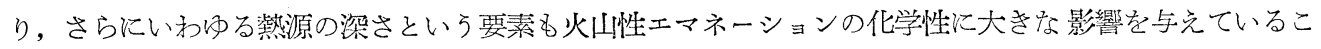
とが判る。火山地带は最も浅い火山活動の場であり, 從つて火山地带温泉の地域恎も, この浅い蓺源の存 在に支配され，比皎的多㥞な化学性で特徴つけられるとみなすことができる。 


\section{文献}

1）野口喜三雄，上野精一：大分県別府白竜噴 気孔の化学成分, 工技庁地熱発電試験研究 報告書(第一集)，1952（昭 27）

2) 中村久由, 安藤武: 大分県大岳地熱地帯調 查報告一特に変質带と噴気温泉との関係 とついてー, 地調月報, 5 巻 8 号, 1954 (昭 29)

3）地熱グループ：宮城県鬼首地熱地带の基 礎的研究, 近刊

4）地熱調查班：鹿児島霧島地熱地带調查報 告, 地調月報, 6 巻 10 号, 1955 (昭 30)

5) 中村久由, 前田憲二郎, 鈴木孝: 秋田県秋 の宮・皆瀬温泉調查報告, 地調月報, 6 巻 11 号, 1955 (昭 30)
6) 中村久由, 比留川貴: 群馬県万座温泉調查 報告一特飞变質带と噴気・温泉との関係一 地調月報, 8 巻 1 号, 1957 (昭 32)

7) 地熱調查班: 宮崎県海老野地熱地带調查 報告, 地調月報, 6 巻 10 号, 1955 (昭 30)

8）角清愛：岩手県松川地熱地帯地質調查報 告，地質調查所受託調查資料

9) A. Steiner: Hydrothermal Rock Alteration at Wairakei, New Zealand. Econ. Geol. Vol. 48, No. 1, 1953

10）静岡県衞生部編：静岡県伊豆地方温泉調 查報告, 静岡県衞生部, 1957 (昭 32)

11）野口喜三雄, 上野精一: 玉川温泉調查報告, 玉川温泉研究十週年誌, 1954 (昭 29) 